Power and Discourse in Policy Diffusion:

Anti-Money Laundering in Developing States

\title{
ACKNOWLEDGEMENTS
}

I would like to thank Percy S. Mistry, Leonard Seabrooke, Mark Blyth, Ove Pedersen, David Marsh, all the participants in the Discourse in International Political Economy Research workshops in Sydney and Copenhagen, as well as three anonymous referees for their contributions and feedback on earlier versions of this paper. I would also like to acknowledge the generous financial support of Australian Research Council grants DP0452269 and DP0771521. 


\begin{abstract}
Twenty years ago not a single country had a policy against money laundering; currently over 170 have very similar anti-money laundering (AML) policies in place. Why have so many countries with so little in common adopted the same policy so rapidly? This extensive diffusion is particularly puzzling given the lack of evidence that AML policies actually work. In explaining the international spread of AML policies, this article draws on recent literature from International Relations, sociology, comparative politics and public policy dealing with policy diffusion and policy transfer, but also differs from most of this work in two key aspects. First, it is argued that the process of diffusion in the developing world has been much more power-based than voluntary. Second, the mechanisms driving policy diffusion (direct coercion, mimicry and competition) are all shown to be discursively-mediated exercises of power, rather than reflecting rational learning or brute material forces. Evidence is drawn from surveys, interviews, and participant-observation in developing countries from three regions.
\end{abstract}


Before 1986 money laundering was not a crime anywhere in the world. Currently, however, over 170 states have criminalized money laundering, and most of these have set up specialized agencies to combat it. The central puzzle this change poses is why so many states with so little in common have adopted the same policy package so rapidly. This spread represents an example of "sameness amid diversity" that has been studied by those interested in the related instances of policy learning and transfer in public policy, policy diffusion and socialization in comparative politics and International Relations, and organizational isomorphism in sociology. In each case research has been stimulated by the belief that the determinants of national policies and institutions are increasingly to be found at the international level, rather than domestically as was conventionally supposed. This article argues that the diffusion of antimoney laundering (AML) policy among developing countries has been driven by discursive, power-based mechanisms.

Aside from showing that there is a puzzle to be examined (why do states with almost nothing in common tend to opt for the same policies around the same time?), scholars from various traditions have advanced a common set of causal mechanisms said to potentially explain this phenomenon. Four of the most common mechanisms advanced are: learning or lessondrawing; coercion; mimicry or emulation; and competition effects. There are others (e.g. US hegemony), but these four recur frequently amongst scholars studying diffusion across the various disciplines and sub-disciplines (Evans and Davies 1999; Drezner 2001; Weyland 2004, 2005; Simmon and Elkins 2004; Simmons, Dobbins and Garrett 2006; Braun and Gilardi 2006; Meyer et al. 1997; Boli and Thomas 1999; Guler et al. 2002). Those researching this issue from a public policy background have further constructed typologies to calibrate the degree to which policy transfer occurs on a voluntary or coerced basis, and the degree to which the resulting 
policy is effective or ineffective (Dolowitz and Marsh 2000). Thus scholars now have a good number of potential mechanisms and helpful typologies to apply to instances of policy diffusion. The next step in pushing forward this research program is to see how these fare in explaining empirical developments.

In terms of the continuum from purely coercive to purely voluntary policy transfer, this article maintains that the diffusion of AML policies in the developing world has generally taken place on a coercive basis. Rational and boundedly rational learning have played little or no role. In addition to direct coercion, mimicry and competition effects have also been important, with all three mechanisms held to be discursively-mediated exercises of power. Although a runaway success in terms of the extent of its diffusion, there is as yet little evidence to show that AML policy is effective in stopping criminals obscuring the illegal origins of their money, whether in developed or developing world contexts. Although the policy is widely lauded and copied, there is very little evidence to show it actually works. AML policy thus may well be a case of “politically successful policy failure” (Peter Andreas, New York Times 13 June 2004).

After providing some background on the development of AML policy, the article begins by refuting the baseline position that a large number of countries have adopted the same policy around the same time after rationally learning (in either a synoptic or bounded sense) how to combat common problems. This section further argues that AML policy in the developing world is not cost-effective, that is, it produces definite and politically high-profile costs but few if any observable benefits. Instead of learning, direct coercion in the form of blacklisting, mimicry in line with changing conceptions of social acceptance in transnational networks of regulators, and competition effects resulting from subjective risk ratings have been key. These three related mechanisms have brought about change primarily (though not exclusively) through discursively- 
mediated processes, rather than through simple, rational responses to material incentives and disincentives. The first mechanism, coercion as blacklisting, was a deliberate and calculated use of power by the Financial Action Task Force (FATF) to impose AML policies that elicited instrumental compliance by states. The second mechanism, mimicry, saw governments adopt AML policy in line with changing social expectations among transnational networks of regulators that defined these laws as something all progressive, modern states should have. Competition effects arose as private firms constructed subjective proxies for AML risk, incidentally creating material penalties for those states that failed to adopt functionally ineffectual but symbolically important AML policies.

TABLE 1: MECHANISMS OF AML POLICY DIFFUSION

\begin{tabular}{|l|l|l|l|l|}
\hline Mechanism & Instantiation & $\begin{array}{l}\text { Type of } \\
\text { power } \\
\text { exercise }\end{array}$ & $\begin{array}{l}\text { Type of } \\
\text { compliance }\end{array}$ & Key actor \\
\hline Coercion & Blacklisting & $\begin{array}{l}\text { Centralized } \\
\text { Instrumental }\end{array}$ & Instrumental & FATF \\
\hline Mimicry & $\begin{array}{l}\text { Social } \\
\text { acceptance }\end{array}$ & $\begin{array}{l}\text { Decentralized } \\
\text { Non- } \\
\text { instrumental }\end{array}$ & $\begin{array}{l}\text { Non- } \\
\text { instrumental }\end{array}$ & $\begin{array}{l}\text { Transnational } \\
\text { regulatory } \\
\text { networks }\end{array}$ \\
\hline Competition & Risk ratings & $\begin{array}{l}\text { Decentralized } \\
\text { Non- } \\
\text { instrumental }\end{array}$ & Instrumental & Firms \\
\hline
\end{tabular}

It bears emphasizing right from the start that these three mechanisms worked in combination. Their separation in the table above is primarily for analytic purposes. The closer one comes to the empirics, the more difficult it becomes to look at the influence of these mechanisms in 
isolation. Rather than being stand-alone or working in an additive fashion, the mechanisms are logically inter-related and temporally sequenced. Blacklisting first created the impetus for a critical mass of developing states to instrumentally adopt AML policies. Subsequently, the unintended working of mimicry and competition entrenched this policy among initial waves of adaptors, and heightened pressure on the rest to emulate the policy model.

\section{METHOD AND CASES}

Following Barnett and Duvall, this article defines power as "the production, in and through social relations, of effects that shape the capacities of actors to determine their circumstances and fate," and discourse as "the social processes and systems of knowledge through which meaning is produced, fixed, lived, experienced and transformed” (2005, 39, 55). These authors recognize that approaches focusing on discourse are well suited to fleshing out the indirect effects of power $(2005,48)$. The emphasis on discourse is not meant to signal some exotic left bank of the Seine world-view; the article presents a constructivist explanation premised on causality and evidence (Finnemore and Sikkink 2001; Milliken 1999; Schmidt and Radaelli 2004), albeit with greater than usual attention to power. Examples of discourse include the written and verbal composition, discussion, and interpretation of press releases by international organizations and governments; technical manuals and reports by transnational networks of regulators, as well as their participation in workshops, seminars and plenary meetings; and the symbolic use of institutions and policies that have little practical purpose. As such it includes both the content of ideas, and the process of interaction and collective interpretation (Schmidt and Radaelli 2004, 184). 
Discourse is relevant to power because it can produce direct and indirect effects, which may be intangible or tangible. Although being excommunicated in the middle ages is a discursive exercise while a twentieth-century strategic bombing campaign is not, both are exercises of power. Both may have material effects, even though excommunication is not a material action. As with the structure of the international system or economy, discourse can also constitute power in a much more indirect sense, endowing some actors with privileges and prerogatives not enjoyed by others (Hajer 1995, 42). For example, it is now believed that, in combination with other factors, previous habits of speech tended to exclude women and minorities from senior positions in universities and the economy more generally. This article does not claim that discourse is the only thing that counts, or the only kind of power, either in the specific explanation presented or more generally. The argument includes a major role for rational strategic interaction and material economic stakes. Nor does the article claim that discourse works in splendid isolation; rather predictably, it works in combination with material factors (Blyth et al. 2008), and the explanation seeks to show specifically how this can happen.

Why, then, the emphasis on discourse, described by one prominent critic as "a swamp of impenetrable jargon that purports to be about language and symbols” (Evans 1995, 2)? Firstly and most importantly because the policy actors involved, in governments, international organizations and private firms, care deeply about words, representations and symbols. Sentiments like "the perception is the reality" slip easy from the lips of those in the financial sector. An international summit involving ministerial delegations from over 50 countries was deadlocked for hours over which of two possible versions of a sentence to include in the final communiqué, despite the complete absence of material stakes:

1. "They also recognized the costs of compliance with relevant international [AML] standards 
and rules, which are particularly heavy for some small developing financial centers.” Or: 2. "They also recognized the costs of compliance with relevant international [AML] standards and rules, which may be particularly heavy for some small developing financial centers.” (At the same meeting "Highly Indebted Poor Countries" petitioned to have the word "Poor" removed from this term: "Ministers took note of the desire of ... HIPCs to seek a new terminology to categorize countries concerned, given the negative connotation associated with current terminology.”) Governments and businesses pay millions of dollars to determine just which slogan, which font, and which shade of blue best communicate financial stability, soundness and probity to foreign investors (van Ham 2002). Successful criminal prosecutions for money laundering are referred to by insiders as “heads on sticks” (Author’s interview 2006): exemplary penalties that are meant to "send a message" to domestic and international society.

The article is in some ways a study of a study. The author jointly led a project on behalf of an inter-governmental organization specializing in technical assistance for the financial sector in developing countries. The goal of this project was to assess the costs and benefits of AML policy for developing countries, focusing specifically on Barbados in the Caribbean, Mauritius in the Indian Ocean and Vanuatu in the Pacific. As such, the article includes a pronounced participant-observation perspective. The cost-benefit analysis (or more formally Regulatory Impact Assessment) began with elite interviews with senior regulators and representatives from the private sector during a preliminary visit by the author to Mauritius, and two trips each to Barbados and Vanuatu. This was followed by a survey conducted by local researchers of regulators and private sector firms to quantify the impact of AML regulations. The findings of the elite interviews and surveys were combined into a summary document for each country and circulated among respondents. The preliminary results were then refined in light of feedback 
received. Workshops involving between 20 and 80 participants in each country (private sector representatives and regulators) were then held in early 2006 to gain further responses to the revised country reports. Public sector representatives included officials from finance ministries, Financial Intelligence Units, central banks, tax administrations, company registrars, insurance supervisors and public investment promotion agencies. Private sector representatives included those from banking, accountancy, insurance, funds management, corporate service provider and trust formation firms. Although not deliberately styled as focus groups, the workshops did provide some of the benefits Hopf (2002) identifies for this technique, in terms of representing a half-way house between one-on-one elite interviews and the quantitative surveys. A synthetic report drawing lessons from the three counties was then discussed at a further workshop with international organizations, including the World Bank, International Monetary Fund, Organization for Economic Co-operation and Development and the Commonwealth.

The end result of this rather lengthy process was a quantitative Regulatory Impact Assessment providing estimates of the costs and benefits of applying international AML standards to the three countries in question. Much more importantly for the purposes of this article, however, was the series of individual and group discussions with those charged with applying AML regulations in developing countries from the public and private sectors. This process also gave the chance to observe developing country regulators with their counterparts from developed countries and international organizations. The iterative process of cycling through various drafts and comparing experiences in different regions repeatedly came back to the question of why the countries had adopted the regulations in the first place. The question became even more pertinent once it became apparent that the costs substantially outweighed the benefits for each country. The answer was outside the scope of the cost-benefit analysis, but is 
the central concern of this piece.

Aside from this participant-observation aspect, the approach taken here is distinctive in several respects. Relating to case selection, most of the work on policy diffusion has either been large- $N$ quantitative studies using global data (Simmons and Elkins 2004; special issue of International Organization 2006; Thomas et al. 1987; Strang 1991; Guler et al. 2002), or small$N$ studies within one region (Weyland 2004; Radaelli 2000; Larmour 2005). In contrast, this article is a small- $N$ cross-regional study. What is lost is the ability to study the global pattern of diffusion, typically a sigma-curve of a few early adopters, followed by a rush of policy bandwagoneers, with a few late-comers and hold-outs (Finnemore and Sikkink 1998; Braun and Gilardi 2006). But a qualitative approach does help to compensate for some of the limitations of large- $N$ studies. These limitations may include looking at cases of policy change as independent instances when they are in fact interdependent (“Galton’s problem,” see Jahn 2006; Braun and Gilardi 2006); making strong homogenizing assumptions about cases; and assuming the uniform causal influence of different mechanisms across time and space (Meseguer and Gilardi 2006). More positively, the in-depth study of a few cases allows for greater attention to processes and causal mechanisms, widely regarded as an area of weakness in the policy diffusion and related literatures (Dolowitz 2000, 3; Drezner 2005, 841; Meseguer and Gilardi 2006, 2; Weyland 2005, 264; Braun and Gilardi 2006, 298; Checkel 2005, 806; Alderson 2001, 432). Aside from being regional, most qualitative studies of policy diffusion analyze developed states (typically in Europe) rather than developing (Drezner 2001, 65; for notable exceptions see Larmour 2005 on the Pacific islands and Weyland 2005 on Latin America). Finally, rather than concentrating exclusively on policy-makers, the views of those private domestic interests affected by policy change are also included in this study. 
The three main cases, Barbados, Mauritius and Vanuatu, are all small developing countries. Because each was an early mover relative to developing countries in general and in their region, adopting AML policies from 2000, there is sufficient track record to judge the impact and effects of this policy. Importantly, none has been classified as posing a high money laundering risk by either the FATF or the US government. Some concerns were noted about Mauritian legislation by the FATF in 2000 (FATF 2000, 7), but these were not sufficient to warrant inclusion on the blacklist of 23 countries identified as deficient in their money laundering standards. The US State Department International Narcotics Control Strategy Report has rated Barbados and Vanuatu as medium-risk for money laundering (Countries of Concern) and Mauritius as low-risk, as opposed to the 50-odd high-risk Countries of Primary Concern, including the United States itself (INCSR 2002, 2005, 2007). At the same time, because each country hosts a modest offshore finance sector, it is unlikely that they have radically less money laundering than other developing countries.

\section{BACKGROUND OF AML}

Money laundering is the practice of obscuring the illegal origins of money gained from crime. With the rise of both cross-border crime and the growth in legitimate international finance and trade, money laundering is argued to have taken on an increasingly global character. To a greater and greater extent, criminals have faced the problem of returning “dirty money” from foreign markets to their home country. But there are also increased opportunities for disguising the true source of this money. Those looking to escape the long arm of the law are said to take advantage of the relative ease and speed of using international banking and financial systems, 
compared with the difficulties and delays associated with co-operation between different national police and judicial institutions. This rendering of money laundering as an international policy problem is a close fit with more general anxieties about how economic globalization is said to threaten to undermine states’ regulatory capacity. More than any other single issue, concerns about the international drug trade in the 1980s put money laundering on the policy agenda as a problem requiring a co-ordinated international response. But through the 1990s both legislation and police practice in fighting money laundering greatly expanded. Since the turn of the century, and particularly since the terrorist attacks of September 2001, money laundering has been seen to provide an umbrella term for a wide range of financial crimes.

In line with more general fears about "the dark side of globalization,” international organizations have been able to argue persuasively that the borderless nature of the problem meant that the only effective response would be one co-ordinated internationally, that is, managed by international organizations (Barnett and Finnemore 2004, 9). Although this response has involved a vast range of general and specialized institutions, from the United Nations to the International Association of Insurance Supervisors, one in particular has taken the lead in defining and spreading international AML standards: the Financial Action Task Force (FATF). The FATF was created in 1990 as an ad hoc group of experts from OECD member countries entrusted with defining the state of the art in AML policy. The result was the 40 Recommendations laying out best international AML practice. Although the Recommendations have been periodically revised since 1990, with 9 Special Recommendations on the financing of terrorism added from 2001, the provisions have remained substantially the same. The general idea has been to collect more financial information on firms and individuals, and use this to find, freeze and confiscate criminals' money. Attacking criminals' financial flows would remove the 
means (working capital) and motive (profit) for the associated crimes.

The FATF echoed the earlier 1988 UN Vienna Convention in stressing the importance of legislating to criminalize money laundering and enhancing international co-operation in keeping with the borderless nature of the threat. In a crucial departure from the Vienna Convention, however, the Recommendations held that the criminal justice system was not sufficient to tackle money laundering by itself. Instead, it was necessary to concentrate on preventing money laundering through regulating private financial intermediaries, particularly banks (Gilmore 1995). Subsequently it has been private financial firms, following FATF-mandated rules legislated by national governments, that have borne most of the burden of fighting money laundering. Specifically, banks and other financial institutions are required to apply due diligence or "Know Your Customer" rules, meaning that they must verify the true identity of those opening accounts with reference to passports, driver's licenses, and so on. Banks have further been placed under the obligation to report "suspicious transactions" (for instance, customers depositing large amounts of cash) to specially created public Financial Intelligence Units. The coverage of these due diligence and suspicious transaction reporting regulations has progressively been expanded from banks to include other businesses such as insurance companies, law firms, bureaux de change, check cashing offices, casinos, etc.

Until the late 1990s, money laundering was largely the concern of the developed world. The FATF worked to diffuse AML best practice by peer-review of members (Levi and Gilmore 2002). But a narrative that emphasized the system was "only as strong as the weakest link in the chain," that criminals would simply avoid countries with tough AML standard by re-routing their finances through countries that had no such laws, created pressure for change. The goal became to include every country in the coverage of AML laws (Wechsler 2001). To this end, the FATF 
began work compiling a blacklist of countries (discussed below) that were regarded as facilitating money laundering through weak laws and/or enforcement. At around the same time, and with the assistance of the Bretton Woods institutions, a slew of regional bodies were created to ensure the spread of AML policies to every part of the globe via "seminar diplomacy" and peer review (Adler and Barnett 1998; Levi and Gilmore 2002; Pagani 2002). There is now one body each for the Caribbean, South America, the Middle East and North Africa, Western Europe, Eurasia, the Asia-Pacific, South and East Africa, and West Africa. Each of these organizations, significantly known as "FATF-Style Regional Bodies," has the core aim of diffusing the same 40+9 Recommendations on anti-money laundering policy.

\section{EFFECTIVENESS AND COST-EFFECTIVENESS}

Earlier public policy work on policy transfer tended to emphasize learning effects between countries (Rose 1991; Dolowitz and March 1996). Policies proven to be effective in one country would be adopted (but also adapted) by policy-makers elsewhere to replicate earlier successful policy outcomes in pioneering countries. In relation to anti-money laundering policy, however, there has been little evidence of policy effectiveness. This is true whether effectiveness is taken in absolute terms, as success in disrupting criminal finance and the underlying illicit activities, or in terms of cost effectiveness, that is whether the regulation produces benefits for society greater than the costs of the regulation itself. This latter approach is advanced by the OECD as constituting best international practice in assessing regulation. A majority of OECD countries routinely carry out or even legally mandate the use of Regulatory Impact Assessments or Regulatory Impact Statements to this end (OECD 1997). If effectiveness and cost- 
effectiveness are at best unproven in the developed states for which this policy was originally developed, this goes even more so for developing countries with their very different economic and social conditions.

Measuring the effectiveness of policy designed to counter money laundering is inherently difficult. It is hard to specify the scale of money laundering either before or after AML policies are introduced, and thus hard also to measure the effect (if any) of the policy changes. More or less plausible stories have filled the gap left by the lack of hard evidence. Most OECD members have had very few successful convictions for money laundering (less than a dozen), and have confiscated only very small sums of dirty money (Rider 2004). Sometimes these small totals are presented as a indicator of success: AML policies have deterred criminals from laundering money by excluding them from the legitimate financial system. However the United States has had many more convictions, up to a thousand (Cueller 2003). Here large totals are also presented as an indicator of success: AML policies have put criminals behind bars and led to the confiscation of the proceeds of crime. Crucially, the FATF has endorsed the latter version, specifying that the number of convictions and asset confiscations are the appropriate measures of effectiveness (FATF 2004, 4-5; FATF 2007, 10-11), and this view has in turn been adopted by the Bretton Woods institutions and the UN.

A more sophisticated recent approach is to measure the cost of laundering money to criminals, in the same way that the street price of illegal drugs is used to measure the impact of drug control strategies. Although the evidence is so far preliminary, in the UK it only costs criminals around 5-10 percent of the principal to launder their ill-gotten gains ("Looking in the Wrong Places,” Economist, 20 October 2005). This in a country which has one of the toughest and most far-reaching (and thus most expensive) AML policies. As one UN report put it, money 
laundering is "an area usually characterized by criminal successes and law enforcement failures" (1998, 3). Probably the most thorough study of cost-effectiveness conducted so far, assessing the United States, concluded: "Little systematic evidence has been advanced that... extensions of the AML regime, with the costs they impose on legitimate businesses and their customers, will do more than marginally inconvenience those who need to launder the proceeds of their crimes" (Reuter and Truman 2004, 7).

Rather than casting doubt on the basic policy model, however, the meager results of AML policies in developed countries are presented as evidence for the need for a re-doubling of efforts, bigger budgets, and more legislative powers for AML agencies. This expansionary dynamic is occurring despite increasing evidence that due diligence and Know Your Customer requirements are creating a significant burden for financial firms and ultimately consumers (but also a lucrative industry for AML consultants) (PWC 2005; Chaikin 2006; KPMG 2007). In sum, because of considerable doubts concerning its effectiveness among early adopters, AML policy is not a natural candidate for policy diffusion via rational learning or lesson-drawing. It lacks even a high-profile national success story that might act as a focal point for boundedly rational learning. The US-led "war on drugs" that first put the issue of money laundering on the agenda is hardly a textbook public policy success. And yet this policy has diffused, throughout the OECD countries, and now in the developing world.

The effectiveness of AML policies among developing countries is even more uncertain, both because of the inherent measurement difficulties referred to above, and because of the policy's short track record in this context. The best evidence available (though far from perfect) derives from the study of Barbados, Mauritius and Vanuatu. As noted earlier, these three have been adjudged as neither atypically high- or low-risk countries for money laundering. All three 
countries adopted the standard model of AML policy as summarized in the $40+9$

Recommendations from 2000 (relatively early), though further modifications have taken place subsequently. Specifically, this model comprises: legislating to make money laundering a criminal offence; allowing for the freezing and confiscation of criminal funds; ratifying international conventions to this effect; instituting due diligence and Know Your Customer requirements for banks and other financial institutions; mandating the identification of ultimate owners and beneficiaries of companies, partnerships and trusts; establishing a suspicious transactions reporting regime for banks and other firms; creating Financial Intelligence Units to process these reports and liaise between financial institutions and law enforcement bodies; and allowing financial intelligence to be shared with foreign law enforcement and regulatory agencies.

So far there is very little evidence that these new measures have made life more difficult for criminals seeking to launder money. No convictions have been obtained in the three countries. The legislative provisions for confiscating criminal assets have so far not been employed (remembering that according to the FATF convictions and confiscation are the primary indicators of effectiveness). Even some in the local Financial Intelligence Units question the suitability of the standard template for local conditions. Whereas electronic transfers are the norm in OECD countries, developing countries depend much more heavily on anonymous cash and barter transactions. In Vanuatu the initial draft of AML legislation was found to be a wordfor-word copy of a UN model, including provisions for complex financial derivatives that do not exist in the country. The thresholds for what constitutes a "suspicious" cash deposit have been set so low that banks have to lodge a report every time local supermarkets deposit their daily takings. 
Weyland writes that countries will adopt ineffective policies to legitimate themselves internationally only when such measures are cheap, or at least where costs are diffuse and thus politically low-profile $(2005,277)$. However this is not the case with AML policy in the developing world. After examining government reports, surveying the public and private sector, conducting interviews and submitting initial conclusions for feedback and review from local representatives, it was possible to come up with some tentative figures on the net cost of AML policies. These ran in the order of $\$ 10$ million annually for Barbados and Mauritius and $\$ 1.5$ million annually for Vanuatu in the period 2002-05, substantial sums for small poor countries with a multitude of other priorities. Nor were these costs politically low-profile. In Mauritius, for example, every bank and insurance company had to contact every single bank account- and policy-holder and ask them to report in person with identification (including the Prime Minister, who complained about the inconvenience). Those that failed to show up had their accounts and policies frozen. Private firms had to publicize the new policy requirements, bear the expense of contacting all their customers, and deal with the thousands of complaints and disputes that arose as a result. The insurance industry association had to spend half its annual budget employing foreign consultants to manage the effects of the new regulations. In Barbados, insurance and reinsurance companies must check every single customer every single day against a blacklist of suspicious names. For reinsurance firms the Know Your Customer requirement has proved particularly troublesome, as by its nature reinsurance deals with pools of secondary risk, not particular people or firms. Firms have had to design expensive new software to cope with this requirement. In Vanuatu the law mandating that offshore shell banks must have "mind and management” within the country (that is, an office containing all financial records and with at least one full-time employee) effectively destroyed the offshore banking industry. The number of 
offshore banks fell from 37 to 7 in the six months after the new regulations were introduced.

According to the rational model, policy-makers should seek out evidence of how to make policy more effective and less costly. In these developing countries the primary audience for AML authorities to satisfy has not been the local financial services industry or government, but rather international organizations and foreign firms (discussed below). As such, evidence that policies created little domestic benefit for considerable cost is seen by local regulators as largely beside the point. A considerable number in the private sector take the same view. The findings that AML standards had a significant net negative impact on these three developing countries generated a hostile response from the organization funding the study, as well as from all developed countries providing feedback. The objection was that such a conclusion could jeopardize the further diffusion of AML standards in the developing world, and thus that the findings should be re-written to reflect this imperative.

\section{MECHANISMS OF DIFFUSION}

In International Relations at least, power and coercion have been most closely associated with realism and the use of material resources by states (Walt 2002; Barnett and Duvall 2005). Accounts emphasizing the role of culture, norms and language are (still) associated with cooperative relations rather than conflict (Johnston 2005, 1041). A broader view of power from a constructivist perspective in the three mechanisms explained below should help to correct these mistaken beliefs. Power may shape outcomes intentionally by a centralized agent (coercion), or in a de-centralized manner within social peer groups (mimicry) or markets (competition). It may generate effects through calculated compliance (coercion and competition) or via logics of 
appropriateness (mimicry) (see Table 1). There are some similarities between coercion and “first face” or "compulsory” power, mimicry and "third face” or "productive” power, and competition and “second face” or “institutional” power (Lukes 1974; Barnett and Duvall 2005). Although these instances of power may (or may not) create material effects, they cannot be reduced to these material effects. Once more it bears emphasizing that although the mechanisms are presented separately below, they worked in combination, with blacklisting logically and temporally prior to mimicry and competition.

\section{Coercion and Blacklisting}

The central coercive element in the process of AML policy diffusion has been the "NonCo-operative Countries and Territories” (NCCT) blacklist drawn up by the Financial Action Task Force from June 2000. The FATF began compiling the NCCT list from late 1998 after losing patience with its attempts to lead by example. The US was concerned about financial secrecy and crime (Wechsler 2001), while Europeans countries were also independently worried about tax losses to jurisdictions with opaque financial sectors (Sharman 2006). Initially the FATF seemed to lack coercive options: it has never been able to extend or withhold conditional loans, and, having no formal legal existence itself, cannot make international law. Formal trade sanctions would have required a legal and practical re-invention of the organization, and put member states to significant expense in applying and monitoring these sanctions. As such, neither members nor the FATF as such were in favor. The alternative, establishing a process for publicly branding non-members as non-compliant with respect to money laundering standards, marked a break in its confrontational character. But it was also congruent with prior FATF 
practice of evaluating countries' money laundering laws against the Recommendations, the use of peer pressure, and ad hoc public condemnations of Turkey and the Seychelles for what were felt to be particularly egregious failings (see below). Both member states and other international organizations had used blacklists to try to promote compliance, though perhaps even the FATF itself was surprised as to just how much more successful the NCCT proved to be (Author's interviews US Treasury 2002, FATF 2004).

Over successive rounds 2000-2001, 47 countries were assessed by the FATF, with those 23 jurisdictions not meeting its standards being placed on the blacklist until such time as they legislated and implemented specified AML policies. Although the list did not impose any formal legal sanctions, it did recommend that financial institutions in all states should impose a higher level of scrutiny on transactions going to, from or through a blacklisted jurisdiction (Recommendation 21). Sounding rather underwhelming, this measure proved effective in constricting or evening severing financial flows to blacklisted jurisdictions (Johnson 2001).

At first this blacklist might seem irrelevant to Barbados, Mauritius and Vanuatu, given that none of the three ended up on the list. But in each case, policy-makers and those in the financial services industry strongly believed in the dangers associated with ending up on the list. The demonstration effect ("heads on sticks") of the FATF listing meant that this tactic was not only successful in pushing blacklisted countries into reform, but also served as a powerful warning to others to get their AML policies in order. All three countries under consideration raced to introduce new policies so as to avoid being negatively labeled by the FATF in this manner, especially after being told about damage blacklisting had done to reputations of neighboring countries. In the Caribbean, Antigua and Barbuda, the Cayman Islands, Dominica, Grenada, St Kitts and Nevis and St Vincent and the Grenadines all ended up on the NCCT list. 
Speaking at a regional AML seminar with senior Barbadian officials in the audience, the Antiguan representative began his presentation on the effects of being blacklisted: "God forbid that you should share this experience” (Ferrance 2000). All the Eastern Caribbean countries argued they had suffered heavily from being blacklisted. Many large international banks cut correspondent banking links with counter-parts in the region rather than be tainted by association with 'deviant' jurisdictions (Sharman 2006; Vlcek 2006). Those that did not tended to impose much higher fees on the grounds that these banks needed to recoup the costs of the enhanced scrutiny applied in line with Recommendation 21. These developments also posed a threat to the tourist sector, as foreign hotel-developers worried about their ability to use international financial networks.

In many cases it is difficult to conclusively link material decline to the effects of blacklisting, but the general opinion among government officials and those in the financial services industry was that the lists caused the damage. As a result the blacklisting exercise was, and still is, bitterly resented by those on the receiving end. Thanks to strong regional links in the Caribbean (including the Caribbean Financial Action Task Force, International Trade and Investment Organization, Caribbean Community, Caribbean Technical Assistance Center, Caribbean Association of Regulators of International Business, etc.) the Barbadian government had ample opportunity to hear about the costs of being blacklisted. An even more powerful medium for spreading this cautionary tale was via the personal ties, professional associations and specialist journals that linked the financial services industry in the region and beyond.

In the Indian Ocean and the Pacific Mauritius and Vanuatu drew similar conclusions from their own neighbors. In what proved to be a trial run for the NCCT list, the FATF had publicly condemned the Seychelles in 1996 for offering immunity from extradition for foreigners 
investing \$10 million in approved government investments. Years later, the IMF claimed the effects still lingered, tending to slow the growth of the international financial sector (IMF 2004; Author's interview Seychelles 2005). In perhaps the extreme instance, the Pacific island republic of Nauru had point-blank refused to accept the FATF's ultimatum unless it was compensated to the tune of $\$ 10$ million. The effect of the FATF blacklist led to a de facto financial blockade by private institutions and the complete collapse of the country's financial system. Currently Nauru has not a single functioning bank, and the country has so successfully been stigmatized that now, even after complying with the FATF's demands, no bank is willing to take the reputational risk of opening a branch in the country (Author’s interview Australian government 2006).

In private interviews and regional workshops in Barbados, Mauritius and Vanuatu March-April 2006 those from the public and private sector were unanimous in acknowledging the incredibly powerful threat posed by the FATF blacklist, perhaps the most talked-about issue in the workshops. The head of one Financial Intelligence Unit put it most directly in stating that the blacklist was equivalent to "a gun to the head" of developing countries. The majority of participants felt that the presence of blacklists meant that developing countries simply had no choice but to reform. Either countries would do whatever was required in the area of AML policy to avoid the wrath of the FATF, or the country would be blacklisted and its international financial sector destroyed. Regulators and banking representatives expressed a willingness to pay any price to stay off the blacklist.

Blacklisting is a form of discursive power in two ways. Rather like public trials and executions hundreds of years ago, blacklists are at least as important in promoting compliance amongst those in the audience as in those directly targeted. The FATF was well aware of benefits of "making an example" of some countries and sending a message to the rest (Author's interview 
FATF 2004). But blacklisting is a linguistic move in a deeper sense as well. Adopting John Searle's terminology, blacklisting is a speech act that creates new institutional facts. Searle speaks of institutional facts in the context of assigning a particular status: husband, wife, lawyer, surgeon, president, convicted murderer and so on (1995, 49-51). Objective features or abilities of the person in question are not sufficient to confer the status in question; instead collective intentionality and acceptance following from the ritual actions of authoritative actors are fundamental in transforming the standing of the individual, and thus the way he or she is treated by others. As an authoritative international organization (Barnett and Finnemore 2004), the FATF has been able to confer a new negative status on certain jurisdictions, and thus dramatically affect the way they are treated by others, in this case both states and firms. In direct contrast to rationalist work, language (discourse) here creates a new institutional fact, a new status, rather than just communicating some aspect of underlying reality (Hacking 1999).

Aside from taking a discursive form, blacklisting is a simple exercise of power: A deliberately caused B to do something that B would otherwise not have done. Neither the FATF, nor targeted countries had any illusions about what was going on; one Bretton Woods official noted that there was “nothing subtle” about the NCCT list (Author’s interview 2005). The FATF employed a deliberate and centralized exercise of power and as a result successfully obtained the calculated compliance of developing states. It had greater success in using public condemnation than, for example, the International Labor Organization because the FATF has more prominent standing and greater authority among an audience that controls considerable investment capital and access to international financial networks. For this reason, bodies like the Basel Committee on Banking Supervision could also be expected to wield considerable power if in future they decided to blacklist. 


\section{Mimicry and Social Acceptance}

The mechanism of mimicry is most closely associated with the sociologists Walter Powell and Paul DiMaggio (1991) and the “world culture” literature (Thomas et al.1987; Meyer et al. 1997; Boli and Thomas 1999). Thanks to Martha Finnemore (1996a, 1996b), it is now well understood in International Relations. In its original formulation, policy-makers react to complex and uncertain environments by copying the organizational forms of perceived leaders in the field. Rather than being driven by bounded rationality or cognitive heuristics, it is the desire for legitimacy that is central. States converge on policy solutions so as to share the common values of modern international society, regardless of whether the particular policies or institutional forms are suited to local circumstances or actually solve problems. Indeed, because the large majority of transfers come to the periphery from the core, the presumption is that policy transfers to the developing world will tend to be inappropriate and thus ineffective. The logic of mimicry is illustrated by the comments of arch-cynic Sir Humphrey Appleby, the fictional bureaucratic mandarin in the British television series Yes Prime Minister. Sir Humphrey explains why the government funds the National Arts Council, the Social Science Research Council, the Milk

Marketing Board and the Dumping at Sea Representational Panel, even though according to him none of these institutions serves a real policy purpose, delivers material benefits, or is popular with the electorate: “They are symbols, you don’t fund them for doing work, you fund them to show what you approve of. Most government expenditure is a symbol.” In this sense, creating a Financial Intelligence Unit, for example, is not a means to attack money laundering but instead serves to show peers and reassure policy-makers themselves that they are in line with shared 
values. Unlike in rationalist work where institutions and policies are introduced for practical or functional effects, here it is a symbolic exercise, policy and institutions are valued for their discursive role.

International organizations (governmental and non-governmental) play the leading role in spreading these shared standards of appropriate behavior and organizational form among states. (Boli and Thomas 1999; Barnett and Finnemore 2004). Such a process of emulation may promote similarities between states in areas as diverse as public scientific agencies or patterns of military procurement (Finnemore 1996b; Eyre and Suchman 1996). International organizations may foster a process of socialization, either in the sense of promoting appropriate role playing amongst state officials given international norms, or even inculcating these norms as taken-forgranted maxims of conduct (“type I" and "type II" socialization respectively, Checkel 2005, 804; see also Alderson 2001). This process of emulation has definite echoes in the area of AML, with observers noting over a decade ago that: "Ratification of the Vienna Drug Convention is becoming virtually an indicator of responsible membership in the international anti-drug and anti-money laundering world community” (quoted in Gilmore 1995, 64). The members of the Eastern and Southern African regional AML group emphasize that they are "part of the international community of more than 150 nations which have embraced the [FATF] standard and are implementing measures to combat money laundering” (ESAAMLG 2005, 4).

The conception of mimicry in this article is centered on power. In contrast to the ideas of states or individual officials seeking to reduce uncertainty in complex environments, or receive public praise and enhanced self-esteem (DiMaggio and Powell 1991), mimicry is driven by fear of losing social acceptance. As Weyland puts it: "Governments dread the stigma of backwardness and therefore eagerly adopt policy innovations, regardless of functional needs” 
(2005, 270). Instead of experiencing approbation and enhanced status for their hard work, developing states at best avoid condemnation and ostracism. States are merely achieving minimum accepted international standards, nothing less, nothing more. There is no praise or recognition. Logically, acting to receive a benefit (status enhancement) or avoid a penalty (losing social acceptance) may seem to be equivalents. But politically, shaping the behavior of states or individuals through rewards or penalties are very different propositions. Remembering the definition of power provided earlier (actors' capacity to determine their circumstances and fate), it can be seen that this kind of stigma-avoiding mimicry represents an exercise of power by the community over the individual, albeit in a decentralized form. Those in Barbados, Mauritius and Vanuatu keenly feel the difference between the positive and negative versions of mimicry. "We go to all the expense, jump through all the hoops, meet all the standards, and what thanks do we ever get for it?” was a common sentiment amongst interviewees in all three countries.

By understating the power-based character of mimicry, scholars have also understated to a significant degree the proposition that, at least for the developing world, policy diffusion by mimicry is often a coercive process. And if the dread of stigma rather than the hope of status enhancement drove reform in these early developing country adopters, the same is even more true of those that followed. Harking back to the definition of discourse presented earlier (p.5-6), the policy community is discursively constituted both by the content of its outputs (handbooks, peer evaluations, etc.) and the mode of its interaction (working groups, plenary meetings, etc.). Its power, conferring or withholding sought-after social acceptance rather than material goods, stems from its control over a body of technical knowledge and language, in this case the arcana of AML policy discourse. This is very close to Barnett and Duvall's "productive power": "the socially diffuse production of subjectivity in systems of meaning and knowledge” $(2005,43)$. 
But what evidence is there for the contention that the emulation mechanism at work is one of preserving social acceptance rather than status-enhancement? In all three countries the major puzzle from the interviews and survey results was the disconnect whereby a large majority of regulators identified the AML policy changes as being good for the financial services industry, but these same respondents could not identify any significant material benefits stemming from these changes. Most couldn’t even agree that the reforms had provided competitive benefits for their country in relation to others. It became apparent that the stakes in question are not material, and the peer group or audience was not domestic but rather transnational networks of regulators in and around formal international organizations (Slaughter 2004). Regulators from all three countries are engaged in assessments, meetings, conferences and exchanges conducted with a huge number of international organizations. Prominent amongst these are the FATF-Style Regional Bodies, but also the FATF, World Bank, IMF, OECD, Financial Stability Forum, International Organization of Securities Commissioners, International Association of Insurances Supervisors, Offshore Group of Banking Supervisors, and many others. In all three countries regulators reported spending more and more time and effort participating in and responding to the demands of these bodies, time and effort that could only be freed up at the expense of purely domestic duties. It is symptomatic that in planning the regional workshops it was difficult to pick a date on which the local regulators were not already booked out dealing with visiting international delegations or themselves overseas at conferences.

As regulators have become more enmeshed in these transnational networks, both at a regional and global level, the reference group that determines social standing is regulators' foreign counterparts and assessors, rather than fellow officials at home or private foreign investors. Each of the organizations listed above carries out regular assessments and peer reviews 
in line with a basic standards document (40+9 Recommendations, IOSCO Multilateral Memorandum of Understanding, Basel Core Principles, etc.). National policies are measured up and declared to be either meeting minimum international standards or failing to meet these standards. Organizations shape policy through the desire of national regulators to avoid being seen as derelict in their duties, backwards, or sub-standard by their peers (Pagani 2002). Like most professionals, regulators are troubled if they know others regard them as doing a bad job. Thus in speaking of such regulatory networks Slaughter notes:

Once a network is established, it essentially becomes a conduit for information about members' reputations-even if they didn't have or care about their reputations beforehand. Having and caring about a reputation among one’s peers is a very powerful tool of professional socialization-in the profession of governance no less than in the private or nonprofit sector $(2004,45)$.

Although the FATF is one of her prime examples $(2004,6)$, Slaughter's work does an excellent job of showing the general relevance of this mechanism of social acceptance among transnational networks in many other policy areas: a variety of other financial regulatory communities, law enforcement, intelligence, environmental protection, development, trade and consumer protection (2004, Chapter 1). Although this dynamic is strongest among regulators, she also demonstrates the operation of this mechanism among officials from national judiciaries and legislatures. In general, mimicry as power can be expected to exert strongest influence in technical areas where there is a great deal of regular interaction within a policy defined community pursuing high-profile, valorized ends like fighting crime.

Unlike blacklisting, mimicry is a non-instrumental and decentralized exercise of power that generates non-instrumental compliance. Patterns of social acceptance or shunning among 
regulators are not deliberately created tools to enhance compliance. Those complying with these norms are acting in a non-instrumental fashion according to a logic of appropriateness, not a logic of consequences.

In a logic of appropriateness... behaviors (beliefs as well as actions) are intentional but not willful. They involve fulfilling the obligations of a role in a situation, and so of trying to determine the imperatives of holding a position. Action stems from a conception of necessity, rather than preference (March and Olsen 1989, 160-161).

Furthermore, as Jon Elster has pointed out, it is not possible to reduce the effects of shared conceptions of appropriate behavior to rational avoidance of social sanctions. Applying social sanctions is costly. Saying that those who fail to sanction inappropriate behavior are themselves vulnerable to disapproval creates a problem of infinite regress (Elster 1989, 120).

Despite the fact that the mechanisms can be analytically distinguished in this manner, blacklisting and mimicry are crucially linked in their operation. For socialization to occur, actors must be in regular contact with a community sharing and defined by certain values and practices (Ikenberry and Kupchan 1990; Alderson 2001; Checkel 2005), in this case the transnational AML policy community. The beliefs and standard practices of this group should be seen as the norm. But by itself the mechanism of mimicry poses a problem of origins: if countries do not have AML institutions, why would they have regulators engaged with this transnational community? Relatedly, how does a policy pass over the tipping point from being one alternative among many to an indispensable symbol of international acceptance? Mimicry logically and temporally follows blacklisting, because the NCCT blacklist forced countries that previously had no interest in the transnational AML community to establish and staff regulatory institutions to 
fight money laundering, staff and institutions that then became enmeshed and socialized within this community. Similarly, following the adoption by developed countries, the NCCT list provided the impetus for a critical mass of developing states to adopt AML policies, whereupon they became a marker of international respectability.

\section{Competition and Risk Ratings}

One of the most interesting ways to model policy diffusion is to trace how policy decisions in country A may affect decisions concerning the same policy area in country B (for example, Braun and Gilardi 2006). Instead of independent choices reflecting idiosyncratic domestic circumstances, policy-makers’ choices become interdependent. One example might be in the case of "fiscal externalities." If country A cuts its corporate tax rate this might create pressure for country B to do likewise rather than suffer capital flight and the resulting tax loss (negative fiscal externality) as investors look for higher after-tax returns elsewhere. Policy change in country A may make third parties less or more willing to transact with country B, which may create pressure for policy convergence.

To what degree have competitive forces influenced the diffusion of AML policies amongst developing states? At first glance it would seem that the prevailing tide of liberalization and deregulation would militate against the spread of AML requirements, given the burdens and expense they impose on mobile international investors. Yet in fact the mechanism of competition has produced the opposite effect; the decision of country A to refuse to introduce AML regulations is perceived to make it less, not more, attractive to investors. At first this may seem a simple "dollars and cents" calculation: if the return on investment adjusted for risk is higher in 
country A than country B, investment will flow to the former and away from the latter. If country B is perceived to have a problem with money laundering while country A does not, the same investment flow will result.

But unlike decisions taken on the basis of differential corporate tax rates, inflation, or histories of sovereign debt defaults, there is as yet no objective, reliable way to measure money laundering risk (Lester 2006). There is not even an equivalent of the rough proxy that Transparency International provides for corruption. The FATF's blacklist has been so successful that the last non-co-operative country (Burma) was de-listed in October 2006. The head of the US Financial Crimes Enforcement Network suggested firms may often have apply AML safeguards on a "hunch” (Naylor 2004, 330). The Wolfsberg group, the major international banks' AML think tank, notes in its guidelines that “it is difficult (at times impossible) for an institution to distinguish between legal and illegal transactions, notwithstanding the development and implementation of a reasonably designed risk based approach in an institution’s anti-money laundering program” (Wolfsberg 2006, 1). All G7 countries are classified by the US government as high-risk for money laundering (INCSR 2002, 2005, 2007). But the lack of objective measures does not change the imperative whereby private firms and public regulators feel the need to “do something” to protect the company or country from international money laundering. As explained below, the discursive notion of "rational fictions” are employed to plug the gap. Regulators have increasingly delegated the task of assigning and guarding against AML risk to private firms (PWC 2005; Lester 2006; KPMG 2007), analogously to the way that Basel 2 delegates a greater role for determining capital adequacy requirements to banks. Firms are responsible for assigning risk, and those that get it wrong may incur commercial loss and even criminal prosecution (Lester 2006). Transactions seen as high risk necessitate extra scrutiny and 
safeguards, which means extra expense. Firms may simply decide investing in and transacting with countries they categorize as high risk is simply not worth the trouble. In this environment of fundamental and pervasive ignorance and uncertainty, firms fall back on casual impressions and shared stereotypes in making their judgments about which countries are high- and low-risk when it comes to money laundering. Adopting international AML standards makes a country less likely to be rated as high-risk relative to competitors: "A customer that is a financial institution, for example, regulated in a jurisdiction recognized as having adequate... AML standards... poses less risk from a money laundering perspective than a customer that is unregulated or subject only to minimal AML regulation” (Wolfsberg 2006, 3). This is not so much because AML standards are actually effective in lowering the risk that a given transaction will involve criminal money, but rather it serves as an indicator of membership of an "in-group."

In this sense, the spread of AML standards via competition effects constitutes what McNamara (2002), writing on delegating monetary policy to independent central banks, refers to as a "rational fiction":

Governments choose to delegate not because of narrow functional benefits but rather because delegation has important legitimizing and symbolic properties... This dynamic is rational and instrumental, as suggested by theories of delegation within the principal-agent framework, but only when placed within a very specific cultural and historical context that legitimizes delegation (53).

So too adopting AML policies to impress foreign firms is rational, not because the policy reduces risk or fits with local circumstances, but because it communicates that a country is within the fold.

Consider the case of Malawi. A poor sub-Saharan country, Malawi is not and does not 
aspire to be an international financial center, nor has it been associated with money laundering or the financing of terrorism. Speaking at an international financial summit in September 2006, the Minister of Economics and Planning recounted how his country had come to adopt the standard package of AML regulations. The Minister was told that Malawi needed an AML policy. The Minister replied that Malawi did not have a problem with money laundering, but was informed that this didn't matter. When the Minister asked if the package of laws and standards could be adapted for local conditions he was told no, because then Malawi would not meet international standards in this area. The Minister was further informed that a failure to meet international AML standards would make it harder for individuals and firms in Malawi to transact with the outside world relative to its neighbors, and thus less likely to attract foreign investment. The Minister concluded "We did as we were told"; the country adopted the standard package of AML policies (Author's observation 2006).

A simple utility-maximizing account that does not take into account this "rational fiction" angle provides a radically under-specified explanation of the mechanism at work here. There is no evidence that the presence of AML policies either decreases money laundering risk in the developing countries, or even acts as an indicator of such risk. In this sense it is not rational for developing countries to adopt such policies, or for firms to assign risk on this basis. Absent the discursive context that valorizes AML policy, making it a potent symbol for the benefit of international investors despite its lack of usefulness, these decisions are mystifying. Once again it bears stressing that although symbolic actions (and inaction) may have material effects, they cannot be reduced to these material effects.

Regulators have delegated responsibility to for assessing country AML risk to international banks and other financial firms. These risk ratings determine the competitive 
position of developing countries in terms of their attractiveness as investment destinations and the ease with which they can use financial networks. Because of the lack of objective measures for AML risk, private firms create material incentives for developing countries to adopt AML policy as "rational fictions." Unlike blacklisting, the exercise of power is decentralized (many firms acting in an unco-ordinated manner) and non-instrumental (firms do not aim to promote compliance with AML regulations). But unlike mimicry, compliance is instrumental according to a logic of consequences. Aside from AML and central bank independence, safeguarding investment with symbolic policies may also obtain in other situations where the underlying risks are hard to observe. Anti-corruption agencies may provide a good example of where in an environment of fundamental conceptual and measurement difficulties, international organizations, states and firms favor symbols over functionality (Larmour 2005).

Like mimicry, by itself competition has a problem of origins: for the competitive dynamic and "rational factions" to diffuse AML policy, a certain critical mass of states must have already adopted AML standards. If only a few countries have adopted a policy that is valorized by international investors, then there may be little competitive pressure to change to conform. All other things being equal, there is a self-reinforcing dynamic whereby as the policy diffuses more widely, the pressure to join increases. Hold-outs are seen as ever more out of step, and face more numerous compliant (and thus more attractive) rivals for investment. In releasing its blacklist, the FATF not only successfully pressured the 23 targeted states to adopt its preferred policies, but also set in train self-reinforcing but largely unintended processes of socialization and competition that have now made AML policy a near-universal standard.

\section{HEGEMONY, POWER AND DIFFUSION}


This article began by laying out the four most common mechanisms for explaining policy diffusion in the relevant literature: learning, coercion, mimicry and competition. In advancing a more power-based and discursive view it has been argued that coercion as blacklisting, mimicry as social acceptance, and competition as symbolic risk-ratings provide a superior explanation of the spread of AML policies in the developing world. But International Relations scholars may wonder to what extent a hegemonic actor might explain the policy diffusion in question. According to this logic, homogenization of economic policy is driven by hard or soft US power (Ikenberry and Kupchan 1990; Lake 1993). Although accounts based on hegemony are usually deployed to explain far more macro variables, typically trade openness, rather than particular policies, could American hegemony provide a better explanation of AML diffusion?

Certainly the United States played a more important role than any other single state in establishing anti-money laundering as a policy priority, establishing the FATF, and shifting the FATF toward a coercive blacklisting strategy. Yet little of this occurred over the opposition of other rich countries, most of whom supported these moves, though sometimes for different reasons. Scholars from nearly every theoretical background would agree that the United States has more influence than any other country in most aspects of international policy-making and enforcement, but this does not make them advocates of theories of hegemony. In this tradition, hegemons provide global public goods, either benevolently or coercively. But there is as yet very little evidence that AML policy constitutes such a public good. Nor is there much evidence that the United States or any other country profiting from the global propagation of AML standards. More fundamentally, this approach is generally premised on the dominance of unitary state acting in a rational manner to obtain material pay-offs (Lake 1993, 461). Even Ikenberry and 
Kupchan emphasize that physical conquest and the pursuit of material gain are the motors of hegemonic socialization to a much greater extent than logics of appropriateness (1990, 284, 293, 307). These accounts also leave very little scope for the key role that international organizations and private firms have played in spreading AML standards.

An alternative view of hegemony is premised on the power of a historic bloc, itself comprised of a dominant transnational class, state institutions and ideological apparatus (Gill 1993). Once again, this view of hegemony is intended to explain macro-structures rather than particular policies. The trouble with these and similar perspectives in seeking to explain AML diffusion from a cui bono logic is that it is not clear that anyone gains from the diffusion of AML policy, aside from the AML industry brought into existence after this diffusion had already occurred. It is difficult to fathom why any transnational capitalist elite would want to subject itself to the regulatory burdens of AML policy. Thus although power has been central to policy diffusion in this instance, it has not been hegemonic power.

\section{CONCLUSIONS}

This article has tried to shed light on why so many different countries have copied a policy of only dubious effectiveness by looking at the experiences of three small developing states. The thesis is that AML policy has been diffused in the developing world through the direct and indirect effects of power, rather than through rational learning, in response to brute material pressures, or to address local policy problems. International organizations, transnational networks and firms have directly or indirectly shaped the circumstances and fates of developing states in this area. AML policy has diffused even though its effectiveness is at best unproven and 
despite the significant and politically high-profile costs it creates.

Three mechanisms have driven the process of AML diffusion. Blacklisting has been a calculated, directly coercive exercise of "compulsory” or "first face” power by the FATF. Blacklisting as a speech act created new institutional facts, a new negative status for those on the list. In turn, this negative status was widely linked with material costs (disinvestment). This combined effect sent a powerful message to other third parties who decided to comply preemptively. Unlike blacklisting (the gun to the head), mimicry operated in a decentralized and indirect manner, as adopting AML policies became the norm and thus failure to adopt more and more deviant. As more of their peers adopted the standard package of AML regulations, officials in developing countries felt the need to conform with expectations that AML policy is an essential feature of modern, progressive governance. Yet rather than generating approbation, praise or enhanced self-esteem, mimicry simply avoided the stigma of backwardness. Adopting AML policy has become standard, normal unremarkable behavior. Competition effects produced discursively-mediated material pressures for compliance with international AML standards. Under the rubric of a "risk-based approach," national regulators have increasingly imposed the task of assessing AML risk on private firms. But there is no objective measure of money laundering risk, because both the incidence of money laundering and the effectiveness AML regulation are unknown. Instead, the firms that are most important in this area use conformity with international expectations as a symbolic proxy for AML risk. Faced with these circumstances, developing states instrumentally adopt symbolically useful but functionally ineffective policy to minimize material costs. Firms do not assign risk ratings with the intention of spreading AML standards; diffusion is in this sense an unintended consequence of decentralized actions. The processes of mimicry and competition both followed and were 
catalyzed by blacklisting.

This article is power-based, constructivist explanation of AML policy diffusion based on a small- $N$ cross-regional study designed to tease out the workings of the mechanisms at play. It bears asking whether the findings may be relevant to other areas of global governance. As foreshadowed earlier, there are perhaps five specific (but tentative) implications, and two more general suggestions. The first is that the effect of blacklisting depends on the authority or status of the issuing actor in the eyes of third parties, and the influence these third parties have over the target. Concerning transnational networks, as Slaughter suggests, the need for social acceptance is likely to exert greater influence as interaction increases, and if there is a general consensus on the value of the goal. The more uncertain the measure of a particular phenomenon, the more likely policies will be deployed as symbols. These competition and mimicry mechanisms generally exert a stronger influence once a critical mass of adherents has been reached. However, this dynamic necessitates an explanation of why a tipping point or threshold is reached in the first place. More generally, the argument presented indicates that those studying diffusion in various disciplines should be more sensitive to the direct and indirect effects of coercion. Finally, for International Relations, it should be possible advance power-based explanations that are outside the rationalist and materialist frame, yet still within the mainstream. 


\section{BIBLIOGRAPHY}

Adler, Emanuel and Michael Barnett (Eds). 1998. Security Communities. Cambridge: Cambridge University Press.

Alderson, Kai. 2001. “Making Sense of State Socialization.” Review of International Studies 27 (3): 415-433.

Barnett, Michael and Martha Finnemore. 2004. Rules for the World: International Organizations in Global Politics. Ithaca: Cornell University Press.

Barnett, Michael and Raymond Duvall. 2005. “Power in International Politics.” International Organization 59 (1): 39-75.

Blyth, Mark, Craig Parsons and Rawi Abdelal (2008) “The Case for a Constructivist Political Economy.” In Constructivist Political Economy (forthcoming)

Boli, John and George M. Thomas (Eds). 1999. Constructing the World Culture: International Nongovernmental Organizations Since 1875. San Francisco: Stanford University Press.

Braun, Dietmar and Fabrizio Gilardi. 2006. “Taking ‘Galton’s Problem’ Seriously: Towards a Theory of Policy Diffusion.” Journal of Theoretical Politics 18 (3): 298-322. 
Chaikin, David. 2006. “Costs and Benefits of Anti-Money Laundering Laws.” Conference paper presented at the $24^{\text {th }}$ International Symposium on Economic Crime, Cambridge, United Kingdom.

Checkel, Jeffrey. 2005. "International Institutions and Socialization in Europe: Introduction and Framework.” International Organization 59 (4): 801-26.

Cueller, Mariano-Florentino. 2003. “The Tenuous Relationship Between the Fight Against Money Laundering and the Disruption of Criminal Finance.” Research paper 64, Stanford Law School, Stanford.

Dolowitz, David P. 2000. “Special Issue on Policy Transfer: Introduction.” Governance 13 (1): $1-4$.

Dolowitz, David P. and David Marsh. 1996. "Who Learns from Whom? A Review of the Policy Transfer Literature.” Political Studies 43 (3): 343-57.

Dolowitz, David P. and David Marsh. 2000. "Learning from Abroad: The Role of Policy Transfer in Contemporary Policy-Making.” Governance 13 (1): 5-24.

Drezner, Daniel W. 2001. “Globalization and Policy Convergence.” International Studies Review 3: 53-78. 
Drezner, Daniel W. 2005. “Globalization, Harmonization, and Competition: The Different Pathways to Policy Convergence.” Journal of European Public Policy 12 (5): 841-59.

Elster, Jon. 1989. Nuts and Bolts for the Social Sciences. Cambridge: Cambridge University Press.

ESAAMLG. 2005. ESAAMLG Strategic Plan August 2005-July 2008. Dar es Salaam.

Evans, Mark and Jonathan Davies. 1999. "Understanding Policy Transfer: A Multi-Level, MultiDisciplinary Perspective.” Public Administration 77 (2): 361-85.

Evans, Peter. 1995. "Symposium on the Role of Theory in Comparative Politics.” World Politics 48 (1): $1-10$.

Eyre, Dana P. and Mark C. Suchman. 1996. "Status, Norms and the Proliferation of Conventional Weapons: An Institutional Theory Approach.” In The Culture of National Security, ed. Peter J. Katzenstein. New York: Columbia University Press.

FATF. 2000. First Non-Co-operative Countries and Territories Review. Paris.

FATF. 2004. Methodology Assessing Compliance with the FATF 40 Recommendations and the FATF 9 Special Recommendations. Paris. 
FATF. 2007. AML/CFT Evaluations and Assessments: Handbook for Countries and Assessors. Paris.

Ferrance, Wrenford. 2000. “Case Study: Antigua and Barbuda.” Paper presented at Caribbean Financial Action Task Force conference, Trinidad and Tobago, 5 December.

Finnemore, Martha. 1996a. “Norms, Culture and World Politics: Insight from Sociology’s Institutionalism.” International Organization 50 (2): 325-47.

Finnemore, Martha. 1996b. National Interests in International Society. Ithaca: Cornell University Press.

Finnemore, Martha and Kathryn Sikkink. 1998. "International Norm Dynamics and Political Change.” International Organization 52 (4): 887-917.

Finnemore, Martha and Kathryn Sikkink. 2001. "Taking Stock: The Constructivist Research Program in International Relations and Comparative Politics.” Annual Review of Political Science 4: 391-416.

Gill, Stephen (Ed.). 1993. Gramsci, Historical Materialism and International Relations. Cambridge: Cambridge University Press.

Gilmore, William C. 1995. Dirty Money: The Evolution of Money Laundering Counter- 
Measures. Strasbourg: Council of Europe.

Guler, Isin, Mauro F. Guillen and John Muir Macpherson. 2002. “Global Competition, Institutions, and the Diffusion of Organizational Practices: The International Spread of ISO 9000 Quality Certificates.” Administrative Science Quarterly 47 (2): 207-32.

Hacking, Ian. 1999. The Social Construction of What? Cambridge MA: Harvard University Press.

Hajer, Maarten A.1995. The Politics of Environmental Discourse: Ecological Modernization and the Policy Process. Oxford: Oxford University Press.

Hopf, Ted. 2002. "Making the Future Inevitable: Legitimizing, Naturalizing and Stabilizing. The Transition in Estonia, Ukraine and Uzbekistan.” European Journal of International Relations 8 (3): 403-36.

Ikenberry, G. John and Charles A. Kupchan. 1990. "Socialization and Hegemonic Power." International Organization 44 (2): 283-315.

International Monetary Fund. 2004. Seychelles: Review of Financial Sector Regulation and Supervision. Country Report 04/381. Washington.

International Narcotics Control Strategy Report. 2002. US State Department Bureau of 
International Narcotics and Law Enforcement Affairs. Washington.

International Narcotics Control Strategy Report. 2005. US State Department Bureau of International Narcotics and Law Enforcement Affairs. Washington.

International Narcotics Control Strategy Report. 2007. US State Department Bureau of International Narcotics and Law Enforcement Affairs. Washington.

Jahn, Detlef. 2006. “Globalization as ‘Galton’s Problem’: The Missing Link in the Analysis of Diffusion Patterns in Welfare State Development.” International Organization 60 (2): 401-31

Johnson, Jackie. 2001. “Blacklisting: Initial Results, Responses and Repercussions.” Journal of Money Laundering Control 4 (3): 211-25.

Johnston, Alister Iain. 2005. “Conclusions and Extensions: Toward Mid-Range Theorizing and Beyond Europe.” International Organization 59 (4): 1013-44.

KPMG. 2007. “Global Anti-Money Laundering Survey 2007: How Banks are Facing up to the Challenge.” KPMG International.

Lake, David A. 1993. “Leadership, Hegemony, and the International Economy: Naked Emperor or Tattered Monarch with Potential?” International Studies Quarterly 37 (4): 459-89. 
Larmour, Peter. 2005. Foreign Flowers: Institutional Transfer and Good Governance in the Pacific. Honolulu: University of Hawai’i Press.

Lester, Zoe. 2006. “Risk Management and the Risks Attached to Money Laundering and Terrorist Financing.” Paper presented at Money Laundering Risk Conference, Sydney, Australia, 21 July.

Levi, Michael and William Gilmore. 2002. “Terrorist Finance, Money Laundering and the Rise and Rise of Mutual Evaluation: A New Paradigm for Crime Control?” European Journal of Law Reform 4 (2): 337-64.

Lukes, Steven. 1974. Power: A Radical View. London: Macmillan.

March, James G. and Johan P. Olsen. 1989. Rediscovering Institutions: The Organizational Basis of Politics. New York: Free Press.

McNamara, Kathleen. 2002. "Rational Fictions: Central Bank Independence and the Social Logic of Delegation.” West European Politics 25 (1): 47-76.

Meseguer, Covadonga and Fabrizio Gilardi. 2006. "What's New in the Study of Policy Diffusion? A Critical Review.” Unpublished paper.

Meyer, John W., John Boli, George M. Thomas and Francisco O. Ramirez. 1997. "World- 
Society and the Nation-State.” American Journal of Sociology 103 (1): 144-66.

Milliken, Jennifer. 1999. “A Study of Discourse in International Relations: A Critique of

Research and Methods. European Journal of International Relations 5 (2): 225-54.

OECD. 1997. Regulatory Impact Analysis: Best Practices in OECD Countries. Paris.

Pagani, Fabrazio. 2002. "Peer Review: A Tool for Co-operation and Change: An Analysis of the OECD Working Method.” Paper prepared by Directorate for Legal Affairs for General Secretariat, 11 September.

Powell, Walter W. and Paul J. DiMaggio (Eds). 1991. The New Institutionalism in Organizational Analysis. Chicago: University of Chicago Press.

PricewaterhouseCoopers. 2005. “Anti-Money Laundering: A Global Financial Services Issue.” PricewaterhouseCoopers International.

Radaelli, Claudio M. 2000. "Policy Transfer in the European Union: Institutional Isomorphism as a Source of Legitimacy." Governance 13 (1): 25-43.

Reuter, Peter and Edwin M. Truman. 2004. Chasing Dirty Money: The Fight Against Money Laundering. Washington DC: Institute for International Economics. 
Rider, Barry A.K. 2004. "Law: The War on Terror and the Offshore Centres: The 'New' Perspective?” In Global Financial Crime: Terrorism, Money Laundering and Offshore Centres, ed. Donato Masciandro. Aldershot: Ashgate.

Rose, Richard. 1991. “What is Lesson-Drawing?” Journal of Public Policy 11 (1): 3-30

Searle, John. 1995. The Construction of Social Reality. London: Penguin.

Schmidt, Vivien A. and Claudio M. Radaelli. 2004. "Policy Change and Discourse in Europe: Conceptual and Methodological Issues.” West European Politics 27 (2): 183-210.

Sharman, J.C. 2006. Havens in a Storm: The Struggle for Global Tax Regulation. Ithaca: Cornell University Press.

Simmons, Beth A. and Zachary Elkins. 2004. "The Globalization of Liberalization: Policy Diffusion in the International Political Economy.” American Political Science Review 98 (1): 171-89.

Simmons, Beth A., Frank Dobbin and Geoffrey Garrett. 2006. "Introduction: The International Diffusion of Liberalism.” International Organization 60 (4): 781-810.

Slaughter, Anne-Marie. 2004. A New World Order. Princeton: Princeton University Press. 
Strang, David. 1991. “Anomaly and Commonplace in European Political Expansion: Realist and Institutional Accounts.” International Organization 45 (1): 143-62.

Thomas, George M., John W. Meyer, Francisco Ramirez and John Boli. 1987. Institutional Structure: Constituting State, Society and the Individual. Newbury Park CA: Sage.

van Ham, Peter. 2002. “Branding Territory: Inside the Wonderful Worlds of PR and IR Theory. Millennium 31 (2): 249-69.

Vlcek, William B. 2006. Small States and the Challenge of Sovereignty: Commonwealth Caribbean Offshore Financial Centers and Tax Competition. Ph.D. dissertation, London School of Economics and Political Science.

Walt, Stephen E. 2002. “The Enduring Relevance of the Realist Tradition.” In Political Science: The State of the Discipline, ed. Ira Katznelson and Helen V. Milner. New York: W.W. Norton.

Wechsler, William F. 2001. Follow the Money. Foreign Affairs 80 (1): 40-57.

Weyland, Kurt (Ed.). 2004. Learning from Foreign Models in Latin American Policy Reform. Washington DC: Woodrow Wilson Center and Johns Hopkins University.

Weyland, Kurt. 2005. “Theories of Policy Diffusion: Lessons from Latin American Pension Reform.” World Politics 57 (2): 262-95. 
Wolfsberg Group. 2006. “Wolfsberg Statement on Guidance on a Risk Based Approach for Managing Money Laundering Risks.” March. 